\title{
New specimens of the crested theropod dinosaur Elmisaurus rarus from Mongolia
}

Philip J. Currie, Gregory F. Funston, and Halszka Osmólska

Acta Palaeontologica Polonica 61 (1), 2016: 143-157 doi:http://dx.doi.org/10.4202/app.00130.2014

New specimens of Elmisaurus rarus from the Upper Cretaceous of Mongolia (Nemegt Formation) preserve bones not previously found in "elmisaurids" that help elucidate their relationships to Leptorhynchos elegans and other oviraptorosaurs. Elmisaurus rarus and the North American Leptorhynchos elegans are known from numerous but incomplete specimens that are closely related to, but nevertheless clearly distinguished from, Chirostenotes pergracilis and Epichirostenotes curriei. These specimens include the first known cranial bone attributed to Elmisaurus, the frontal, which clearly shows this animal had a cranial crest (most of which would have been formed by the nasal bones). The first vertebrae, scapula, femora, and tibiae from Elmisaurus are also described. The Elmisaurinae can be distinguished from the Caenagnathinae by the coossification of the tarsometatarsus and smaller size at maturity. Examination of oviraptorosaur hindlimbs reveals four distinct morphotypes, possibly attributable to paleoecological differences.

Key words: Dinosauria, Oviraptorosauria, Caenagnathidae, Elmisaurinae, Cretaceous, Mongolia.

Philip J. Currie [philip.currie@ ualberta.ca] and Gregory F. Funston [funston@ ualberta.ca], Biological Sciences CW405, University of Alberta, Edmonton, Alberta T6G 2E9, Canada. Halszka Osmólska, Instytut Paleobiologii, Polska Akademia Nauk, ul. Twarda 51/55, 00- 818 Warszawa, Poland. Passed away on the 31st of March 2008.

This is an open-access article distributed under the terms of the Creative Commons Attribution License (for details please see creativecommons.org), which permits unrestricted use, distribution, and reproduction in any medium, provided the original author and source are credited. 
FoF Full text $(935.6 \mathrm{kB})$ 